\title{
Legal Review Of Malpractice Notary In The Notary's Deed
}

\author{
Enriko Silalahi ${ }^{1}$ and Akhmad Khisni ${ }^{2}$
}

Abstract. Article 84 and Article 85 of Law No. 2 year 2014 on the amendments to the Act No. 30 year 2004 concerning Notary Public Official, when a Notary in performs his official duties and is proven to have committed a violation, the Notary may be subjected or sanctioned. The sanction is in the form of civil sanction, administration, and code of ethics of Notary. Besides, if a Notary commits a criminal offense, a criminal sanction may be imposed to him.

The purpose of the research was to find out the malpractice of the Notary in the Notary deed, and to find out the role of the Regional Supervisory Board (MPD) in supervising Notaries who carry out malpractice actions.

This study used a juridical-normative approach derived from the collection of primary data and secondary data, then they were analyzed by qualitative analysis methods. Data collection techniques used was library studies with qualitative data analysis.

The result of the research showed that UUJN does not mention the existence of sanction punishment but a legal action against the violation done by Notary. It invites elements of forgery over intent/negligence in making authentic letter/deed which contains false facts. After administrative sanction/professional code of ethics Notary and civil sanctions, as well as qualified are as a criminal act committed by a Notary. If the notary is proven to have been involved in intentionally committing a crime of forgery of an authentic deed the sanction will be given to him/her.

Suggestion to lawmakers to anticipate the different interpretations of the law can be done quickly, so that malpractice Notary will never occur again.

Keywords: Sanctions; Notary; Malpractice; Accountability

\section{Introduction}

Rules in the profession are commonly known as codes of ethics. Any profession that is not in accordance with the rules of the profession can be called by the act of malpractice. Malpractice acts can be subject to criminal or civil sanctions, both in the profession of doctors, advocates, and notaries. An action can be said to be malpractice if it meets the conditions of the existence of the act (do or not do), the act violates the law, there are losses borne by the client. There is a causal relationship between cause and effect, and the element of error or omission.

Value more than a profession is the extent to which a professional is able to withstand the temptation of the trust given to him when the temptation to distort trust is so great. The morality-based foundation is an absolute must to be built and notaries as a top group, have a big share for the wider community in building morality. ${ }^{3}$

Etymologically, malpractice comes from the word mal, meaning wrong, so this malpractice is a wrong procedure that results in a patient's loss or even fatal. In other

\footnotetext{
${ }^{1}$ Deputy Chief of Police of the Resort of Semarang email enriko silalahi@yahoo.com

2 Lecturer of Faculty of Law UNISSULA

${ }^{3}$ Abdul Ghofur Anshori, 2009, Lembaga Kenotariatan Indonesia Perspektif Hukum dan Etika, UII

Press, Yogyakarta, p. 1
} 
words, you can also do criminal acts such as abortus provocatus. ${ }^{4}$ The types of malpractices committed by Notary in carrying out their positions, such as:

- There is a deed made by a Notary but the person does not feel he is coming to the notary, when one of the defenders is facing the Notary has to his minuta deed (the original deed), to see directly the signature, but he is not permitted by the Notary. The notary only gives the copies of the deed. The notary even does not want to show him the attachment of a photocopy of the land certificate that becomes the object of the Notary deed.

- The decision of the criminal justice court against a Notary who does not deposit taxes BPHTB and final PPH tax to the tax office as a liability before the sale deed was made, whereas the parties have submitted / entrusted to Notary for the payment of BPHTB and even the notary made payment slip fake tax as if it had been deposited with the land office and the Notary did not report the sale and purchase deed to the tax office every month.

- The existence of a Notary who pawns the land titles belonging to the entrants entrusted to him.

- The existence of a Notary which makes the Deed of sale and purchase of buildings and the release of state land ownership to each party. However, each party has no ownership in the land is a former HGB state land even though it has just ended.

In Article 84 and Article 85 Act No. 2 year 2014 concerning amendments to Law No. 30 year 2004 concerning Position of Notary, it is stipulated that when a Notary in performing his official duties is proven to have committed a violation, the Notary may be subject to sanctions, in the form of civil sanction, administration, and code of ethics of Notary, and the sanctions have been arranged in such a way as before in the Regulation of the Notary Position. However, the UUJN (Notary Law) and the Code of Ethics of the Notary Position does not regulate the existence of criminal sanctions against the Notary. In practice, it may be found the fact that a notary does legal action or violation, he/she actually be subjected to administrative or civil sanctions or a code of ethics for the position of a Notary, but the violation is qualified as a criminal act committed by a Notary Public. The qualification relates to aspects such as certainty of day, date, month, year and time, party (who is the person) who faces Notary, signature facing, copy of deed not in accordance with the Minuta deed, copy of deed, without minutes of deed and Minuta deed is not signed in full, but the minutes of deed are issued.

If these aspects are proven to be violated by a Notary, the Notary concerned can be subjected to civil or administrative sanctions. If these aspects can be proven, they can be used as a basis for imposing administrative sanctions and civil sanctions on Notaries. On the other hand, these aspects can be used also as a basis for criminalizing Notaries with the basis that Notaries have made fake letters or falsified deeds with qualifications as a criminal act committed by a Notary ${ }^{5}$. The implementation of the responsibility of the Notary for ethical malpractice is a Notary will be subjected to moral sanctions and then will be examined by the Regional Supervisory Board (hereinafter referred to as MPD). Moreover, the Notary will be subjected to legal

\footnotetext{
4 Edi Setiadi, Pertanggungjawaban pidana Dalam Kasus Mal Praktek Dokter, Makalah pada seminar sehari Penegakan Hukum Terhadap Malpraktek, kerjasama antara IKAHI dan IDI Cabang Sekayu di Sekayu

${ }^{5}$ Habib Adjie, 2014, Hukum Notaris Indonesia, Refika Aditama, Bandung, p. 25
} 
sanctions. While the implementation of the responsibility of the Notary for civil malpractice is the Notary will be subjected to civil sanctions in the form of paying fine. In the case of compensation, the MPD acts as a mediator for the Notary and the injured client. This study aimed to determine the Legal Review of Notary Malpractice to the Notary Deed.

\section{Research methods}

The research was conducted based on a normative juridical approach, including research on the principles of law, sources of law, theoretically scientific legislation that can analyze the issues discussed. In this research, the statue approach and the legal concept analysis (analytical \& conceptual approach) approach were used. The statue approach (statue approach) was carried out by examining all laws and regulations relating to legal issues that are handled. The statue is the legislation and regulation ${ }^{6}$. Primary legal material consisted of: The criminal law code, law number 2 year 2002 concerning the Republic of Indonesia National Police, Law No. 2 year 2014 concerning the position of notary public and notary code of ethics, as well as criminal cases. Whereas secondary legal material consisted of the writings of legal experts and other fields that can provide an explanation of primary legal materials.

\section{Research Result And Discussion}

\subsection{Research Results}

\subsubsection{Factors that cause malpractice carried out by a Notary.}

- Internal factors, namely the Factor of Notary as a Related Man

In terms of carrying out his/her duties, the Notary has obligations and the most important thing that is stated in article 16 paragraph 1 (a) UUJN includes acting honestly and impartially. The placement of a Notary with a ratio of population density for the matter of making a notarial deed turned out to cause problems namely the growth of unhealthy competition between Notaries and widespread abuse of authority or deviations of duties of trust as a disgraceful act. These issues increased to unlawful acts and would later lead to the action of Administrative Mal. ${ }^{7}$

\section{- External factors}

- Factors of Legal Substance Related to the scope of the Notary Position according to the Minister of Law and Human Rights.

The appointment of a Notary, approximately 2000 Notaries, stated that the existing formations so far would have a broad impact on the Notary profession. In facing the globalization era, the Notaries are trying to determine the position of their functions and roles.

- Supervisory Factors for Notaries

Prior to the enactment of UUJN, supervision, examination and imposition of sanctions on Notaries were carried out by the existing judiciary as had been regulated in Article 140 of Reglement op de Rechtelijke organisatie en Het

\footnotetext{
${ }^{6}$ Soerjono Soekanto I, Op.Cit, p. 93

7 Wirjono Prodjodikoro, 2000, Perbuatan Melanggar Hukum dipandang dari sudut Hukum Perdata, Mandar Maju Bandung, p. 7
} 
Beleid Der Justitie (Stbl. 1847 No.23), Article 96 of the Regelement Buitengewesten, Article 3 of the Ordonantie Buitengerechtelijke Verrichtingen State Gazette 1946 Number 135, and Article 50 PJN. After that, the supervision of the Notary was carried out by the General Court and the Supreme Court as mentioned in Articles 32 and 54. Many Notaries who are appointed by the police as witnesses or those who lead as suspects cannot be summoned or examined because the process of the Supervisory Board has not permitted this considering the existence of Article 66 of the UUJN which states for the benefit of the judicial process, public prosecutor investigators, or judges with the approval of the Regional Supervisory Council. ${ }^{8}$

\subsubsection{The process of investigation conducted by the Police in handling the criminal act of notary public}

For the purposes of the judicial process, investigators, public prosecutors, or judges with the approval of the Regional Supervisory Board are authorized to take a copy of the Minutes of Deed and/or letters attached to the Minutes of Deed or Notary Protocol in the deposit of Notary Public and call the Notary to attend the examination relating to the deed made or the Notary Protocol which is in the deposit of the Notary ${ }^{9}$. Regarding the procedure for summoning witnesses and suspects by investigators, in Article 112 states that: (1) Investigators who conduct audits, stating the reasons for the call clearly, are authorized to call suspects and witnesses deemed necessary to be examined by a valid summons by observing the grace period. It means the summons is reasonable between the receipt of a call and the day a person is required to fulfill the call. (2) The person who is called must come to the investigator and if he does not come up the investigator will call him again, with an order to the officer to bring him ${ }^{10}$. In general, the summons of witnesses and suspects by the Investigator is carried out directly by not requiring the consent of other parties/officials (Article 66 paragraph (1) KUHAP), namely the Regional Supervisory Council.

\subsection{Discussion}

\subsubsection{Legal Review of Notary Malpractice in Notary Deed}

Notary based on the national legal system, is a general official, namely the State organ that represents and acts for and on behalf of the State in carrying out his/her duties to provide services to the general public in the field of civil law. ${ }^{11}$ As a general official, the Notary is appointed by the State and equipped with general authority, authorized to exercise part of the State's power to make written and authentic evidence in the

\footnotetext{
${ }^{8}$ Interview with, Aiptu Burhan, Semarang Police investigator July 12018

9 Law Number 30 of 2004 concerning Notary Position (State Gazette of the Republic of Indonesia of 2004 Number 117, Supplement to the State Gazette of the Republic of Indonesia Number 4432).

${ }^{10}$ Law Number 8 of 1981 concerning Criminal Procedure Law (State Gazette of the Republic of Indonesia of 1981 Number 76, Supplement to the State Gazette of the Republic of Indonesia Number 3209).

${ }^{11}$ Herlien Budiono, Pertanggungjawaban Notaris Berdasarkan Undang-Undang Nomor 30 Tahun 2004 (Dilema Notaris Diantara Negara, Masyarakat dan Pasar), Majalah Renvoi, Jakarta, 3 September 2004 , p. 32
} 
field of civil law ${ }^{12}$. Notary at this time becomes very important because the Notary by the Law is authorized to make a proof tool in the form of an authentic deed which is essentially considered correct. This is very important for all people who need a means of proof for their needs, both for personal interests and business interests. The making of authentic deeds aims to ensure legal certainty, order and legal protection for interested parties and society as a whole ${ }^{13}$. According to the explanation of Law No. 30 year 2004 concerning the Notary Position, it is explained the importance of the Notary profession that is related to the making of an authentic deed. There is an authentic deed that is required by law in the framework of certainty, order or legal protection. ${ }^{14}$ As for some application of sanctions to the Notary is proven to have committed an authentic deed, the sanctions that can be imposed on the Notary who violates the law are:

- According to Law Number 30 year 2004 concerning Notary Position, namely the application of Administrative sanctions or Notary Code of Ethics

Administratively, law enforcement instruments in the Notary Position Act include preventive measures and repressive measures (Application of sanctions). Preventive measures are carried out through periodic protocol inspection of Notaries and the possibility of a violation of the code of ethics in the implementation of the position of Notary Public. While repressive measures are carried out through the imposition of sanctions by the Regional Supervisory Council, in the form of verbal reprimands and written reprimands and the right to propose to the Central Supervisory Board three (3) months to (six) 6 months and disrespectful dismissal.

- According to the BW in the Civil Code

The act of counterfeiting an authentic deed carried out by a Notary, also fulfilling the elements of the Act against the law in accordance with the elements contained in article 1365 of the Civil Code can be described and fulfilled so that an act can be categorized as unlawful, namely:

- There must be an action (Daad)

- It must violate the law (Onrectmatig)

- According to the Criminal Code

Criminal sanctions are ultimum remedium, namely the last problem solving, if the sanctions or efforts are not effective or are considered not applicable ${ }^{15}$. For a Notary who commits a criminal act a dismissal can be made by the Minister on the grounds that the Notary has been proven guilty and subjected to imprisonment, which is regulated in the Ministerial Decree year 2003 concerning Notary Article 21 paragraph (2) sub b, namely the Notary proven guilty directly related to his position or another criminal offense with a 5 (five) years imprisonment.

Based on the formulation of criminal elements from article 263 of the Criminal Code concerning the forgery of authentic deeds carried out by a Notary, the notary cannot be punished with criminal sanction. However, the Notary may be subjected to

\footnotetext{
${ }^{12}$ Ibid

13 Gunawan Widjaja,2006, Seri Hukum Bisnis Memahami Prinsip Keterbukaan (Aanvullend Recht) Dalam Hukum Perdata, Jakarta, Raja Grafindo Persada, p. 288

14 Makmur, 2013, Analisis Perlindungan Hukum Terhadap Notaris Setelah Berakhir Masa Jabatannya Berdasarkan Undang-Undang Nomor 30 Tahun 2004 Tentang Jabatan Notaris, Jurnal Mercatoria Vol. 6 No. 1, Universitas Meda, p.1

15 Habib Adjie, Jurnal Renvoi, Nomor 10-22 Tanggal 3 Maret 2005, p. 126
} 
sanctions from article 264 of the Indonesian Criminal Code, because article 264 of the Criminal Code contains regulation on counterfeited letter. So that all the elements that differentiate between article 263 and article 264 of the Criminal Code is on the existence of objects of forgery, namely "Kinds of letters and letters containing greater confidence in the truth of its contents". The forgery of the 264 letter above lies in the various factors of the letter. Thus, the punishment of a Notary can only be done with restrictions if:

a. There is a legal action from the Notary against the formal aspect of the intentional deed, full of awareness and conviction and planned. The deed is made before the Notary or by the Notary together (agree) to be used as a basis for a criminal act;

b. There is a legal action from a Notary in making a deed before or by a Notary which if measured by the Notary Position Act (UUJN) is not in accordance with the UUJN and;

c. Notary actions are not appropriate according to the authorized broad which has function to assess an act made by Notary, this is stated in the Notary Supervisory Board. ${ }^{16}$

With the explanation above, the Notary may be convicted of a criminal case, if the action can be proven in court. The Notary intentionally together with the parties makes a deed with the intent and purpose to benefit the party by harming the other parties. Thus, it is concluded that although in the Notary Act (UUJN) did not mention about the application of criminal sanctions, but a legal action against violations committed by the Notary invited elements of forgery on intentional/negligence in the making of an authentic letter/certificate which contents are false. After being subjected to administrative sanctions/code of ethics for the position of Notary Public and civil sanctions, the notary can then be withdrawn and qualified as a criminal act committed by a Notary who explained the existence of evidence of intentionally committing a crime of forgery of authentic deed. ${ }^{17}$

Actually, criminal sanctions can be applied if there is evidence of a violation of law that connects with criminal acts as an alternative part of the settlement of a legal case. Because criminal sanctions are Ultimum Remedium, it is the last problem solving, if the sanctions or efforts in other branches of law do not work. Therefore its use must be limited. ${ }^{18}$ Negligence (culpa) lies between deliberate and coincidental, however the culpa is seen as lighter than deliberate. Hence, the offense of culpa, the culpa is a quasi-criminal (quasideliet) so that a criminal reduction is carried out. Culpa offence contains two kinds, namely negligence offense which results in consequences and which does not cause consequences. However, what is threatened with crime is the act of inadvertence itself, the difference between the two is very easy to understand, namely the negligence that results in the occurrence of the consequence, then create offense negligence, for those who do not need to cause consequences with negligence itself has been threatened with crime. ${ }^{19}$

\subsubsection{The role of the Regional Supervisory Broad (MPD) in supervising Notaries who carry out malpractice actions.}

\footnotetext{
${ }^{16}$ Habib Adjie, Jurnal Renvoi, Nomor 10-22 Tanggal 3 Maret 2005,p. 123

17 Habib adjie,2008, Hukum Notaris Indonesia, Bandung: Refika Aditama, p. 25

18 Habib Adjie, Jurnal Renvoi, Nomor 10-22 Tanggal 3 Maret 2005, p. 31

${ }^{19}$ Ibid., p. 48
} 
The authority of the Regional Supervisory Broad mentioned in Article 70 of the UUJN includes:

- Hold a hearing to check the alleged violation of the Notary Code of Ethics or violation of the implementation of the position of a Notary; and

- Receive reports from the public regarding the alleged violation of the Notary Code of Ethics or violation of the provisions in the Law.

UUJN mentions that the mildest sanctions are verbal reprimands. The second sanction is a written warning, and the third, the sanction is a maximum of 6 months' temporary termination. The last sanction is dismissal of his position either with respect or disrespect ${ }^{20}$. In addition, notaries in Indonesia also gathered in one forum of professional organizations, namely the Indonesian Notary Association (Indonesian language: INI or Ikatan Notaris Indonesia) which also has a code of ethics, namely the Notary Code of Ethics. So, in addition to being subject to the UUJN, notaries are also subject to the Notary Ethics Code issued by INI.

Further provisions regarding the examination and imposition of sanctions at the first level by the Honorary Board can be seen in Article 9 of the Notary Code of Ethics. Article 6 of the Notary's Code of Ethics, sanctions that can be imposed on a Notary who violates the Code of Ethics can be: verbal warning, warning, terminating of membership of the Association, onzetting (dismissal) of membership of the Association, dishonorable discharge from membership of the Association. So, in essence if there is a party who is harmed by a notary, the party simply reports to the Regional Supervisory Broead or the Regional Honorary Council if the loss arises due to a violation in the position of a notary or violation of the code of ethics. Or, reported to the police if the act of the notary has been out of office as described previously. ${ }^{21}$

\section{Conclusion}

Notary profession law (UUJN) does not mention the application of criminal sanctions but a legal action against violations committed by the Notary invites elements of forgery on intentional/negligence in making authentic letters/deeds. The deed contents are false. After being subjected to administrative sanctions/Professional code of ethics for the position of Notary and civil sanctions, the sanction can then be withdrawn and qualified as a criminal act committed by a Notary. The sanction is completed with the evidence that a notary intentionally committed a crime of forgery to an authentic deed. The notary cases are regulated in a special law, namely Law Number 30 year 2004 concerning Notary Position related to the Code of Ethics of his profession and there is a Notary Supervisory Board which functions to oversee the duties and authority of Notaries. The application of sanctions Criminal exclusion becomes limited to Notaries. The role of the Regional Supervisory Board (MPD) is supervising Notaries who carry out malpractice actions.

The government should provide special training to Notaries on a regular basis so as not to make fatal mistakes. These mistakes, further, have an adverse influence that can harm both certain parties and notaries themselves in making authentic deeds. Notary who are proved committing violations can be punished based on criminal offence.

\footnotetext{
${ }^{20}$ Interview with, Aiptu Burhan, Semarang Police investigator, July 12018

${ }^{21}$ http://www.hukumonline.com/klinik/detail/lt4fe9dafae18de/langkah-hukum-jika-dirugikan _ oleh-notaris, accessed on 7 July 2018 at 14.00 WIB
} 


\section{References}

[1] Abdul Ghofur Anshori, 2009, Lembaga Kenotariatan Indonesia Perspektif Hukum dan Etika, UII Press, Yogyakarta

[2] Gunawan Widjaja,2006, Seri Hukum Bisnis Memahami Prinsip Keterbukaan (Aanvullend Recht) Dalam Hukum Perdata, Jakarta, Raja Grafindo Persada

[3] Habib Adjie, 2014, Hukum Notaris Indonesia, Refika Aditama, Bandung

[4] Herlien Budiono, Pertanggungjawaban Notaris Berdasarkan Undang-Undang Nomor 30 Tahun 2004 (Dilema Notaris Diantara Negara, Masyarakat dan Pasar), Majalah Renvoi, Jakarta, 3 September 2004

[5] Makmur, 2013, Analisis Perlindungan Hukum Terhadap Notaris Setelah Berakhir Masa Jabatannya Berdasarkan Undang-Undang Nomor 30 Tahun 2004 Tentang Jabatan Notaris,

[6] Undang-Undang Nomor 30 Tahun 2004 tentang Jabatan Notaris (Lembaran Negara Republik Indonesia Tahun 2004 Nomor 117, Tambahan Lembaran Negara Republik Indonesia Nomor 4432).

[7] Undang-Undang Nomor 8 Tahun 1981 tentang Hukum Acara Pidana (Lembaran Negara Republik Indonesia Tahun 1981 Nomor 76, Tambahan Lembaran Negara Republik Indonesia Nomor 3209).

[8] Wawancara, Aiptu Burhan, Anggota penyidik Polda Semarang

[9] Wirjono Prodjodikoro, 2000, Perbuatan Melanggar Hukum dipandang dari sudut Hukum Perdata, Mandar Maju Bandung

[10] Peraturan Menteri Hukum dan Hak Asasi Manusia Nomor M.03.HT.03.10 Tahun 2007 tentang Pengambilan Minuta Akta dan Pemanggilan Notaris

[11] Undang-Undang Nomor 30 Tahun 2004 tentang Jabatan Notaris (Lembaran Negara Republik Indonesia Tahun 2004 Nomor 117, Tambahan Lembaran Negara Republik Indonesia Nomor 4432) 